\title{
A Search Model Where Consumers Choose Quantity Based on Expected Price
}

\author{
Paolo Buccirossi \\ Lear - Laboratorio di economia, \\ antitrust, regolamentazione \\ Via del Banco di S. Spirito, 42 \\ 00186 Rome \\ tel. +390668300530 \\ email: paolo.buccirossi@learlab.it
}

First version October 2001 - Final version June 2003

\begin{abstract}
I describe a price game in which consumers face search costs and base their quantity decision on the expected price. Because of search costs the choice of the firm they will buy from is described by a random process. I show that the expected equilibrium price is above the monopoly price. This result does not change if demand comes from a small share of perfectly informed consumers with zero search costs.
\end{abstract}

Keywords: Imperfect information, Price competition, Search costs

\section{JEL Classification: L13}

Acknowledgments

I would like to thank J. P. Benoit, Giancarlo Spagnolo, Riccardo De Bonis, and Steven Tokar, for helpful comments. 


\section{INTRODUCTION}

This paper describes a market where consumers base their quantity decision on the expected price, as they do not know the identity of the firm they will buy from and therefore the price they will pay, and face search costs when they have to make their purchases. There are several markets in which consumers exhibit this behavior. Roadside or other emergency services provide an example. The quantity of services bought by consumers does not depend on the price paid when the purchase actually occurs, but on decisions that, because they were taken previously, had to be based on the expected price. When consumers actually buy the emergency service, search costs are extremely high because they cannot delay their purchase to acquire the required information. These costs prevent them from searching for the firm with the lowest price. Another example is taxicabs. How much consumers use taxis is determined by the expected price, because they put themselves in a position in which they need a taxi before they know how much the particular taxi charges. Also in this case, search costs may prevent them from choosing the taxi with the lowest price.

A similar situation occurs if the two decisions that a consumer usually has to make, how much to buy and where to buy, are made by two different agents with different incentives/preferences and the quantity decision precedes the choice over which firm to purchase from. For instance, consider purchases made by public agencies through procurement mechanisms. The buyer generally commits to buy a given quantity basing this decision on the expected price. If there is not an incentive mechanism powerful enough to induce a different agent, who is in charge of the selection of suppliers, to choose the cheapest offer, ${ }^{1}$ the expected price differs from the lowest price. The same situation may occur in the pharmaceutical sector, where doctors, who choose the firm to patronize, generally do not have an incentive to select a drug according to the price and the subjects that bear the costs (patients or the National Health System) base their long run quantity decision on the expected price. 
Finally, the same consumers' behavior may emerge in the aftermarkets of durable goods. Consumers, to a large extent, cannot adjust their quantity decisions concerning spare parts or maintenance and repair services in the short run, and may face search costs in the choice of the supplier of these goods and services.

Several economists have analyzed market features that impede perfect selection between firms according to their price, namely search and switching costs, and have described their welfare consequences. The literature on "search models" started with Stigler [1961] and broadened out enormously thereafter. Some of these models focus only on the consumers' side of the story, others propose closed market games where consumers play an effective role choosing their search strategies. $^{2}$ Beggs, Klemperer and others ${ }^{3}$ have analyzed the competitiveness of markets in which consumers face switching costs and therefore may not buy from the lowest price firm.

In the literature dealing with search or switching costs it is implicitly assumed that where and how much to buy are decisions made with identical sets of information and identical preferences. Once consumers have efficiently performed their information gathering activities, they use this information on price to decide where to go to make their purchase and how much to consume. Similarly, if they decide to stick to their suppliers to avoid switching costs, they will base their decision of how much to buy upon the price charged by the firm they are going to buy from. The novelty of this paper is that it analyzes the combined effects of the quantity rigidity described before and search costs.

To simplify the analysis I assume that search costs are so high that the probability of buying from one firm does not depend on the prices charged by it and by its competitors. ${ }^{4}$ Hence, which firm a consumer will buy from is described by a random process which does not depend on relative prices. This assumption can be relaxed without affecting the main results of the model. ${ }^{5}$ However, in the supplemental material I also investigate the case in which an exogenous proportion of consumers are perfectly informed or, equivalently, have zero search costs. 
The result of the paper is that firms respond to this consumers' behavior by charging a price above the monopoly price that would maximize their joint profit. Thus, not just the social planner but also firms would like price regulation that limits price increases. ${ }^{6}$

The rest of the paper is organized as follows. In section 2 I introduce the formal model. In section 3 I analyze market equilibrium when all consumers are uninformed. In section 4 I summarize the result of a model in which some consumers are perfectly informed. Section 5 concludes.

\section{THE MODEL}

I make the following assumptions:

A1) Supply. $n$ firms produce a homogeneous product. They have access to identical technologies which entail no fixed costs and show constant marginal costs, normalized to 0 .

A2) Strategies. Firms compete in price. They choose a price from the set $R_{\dashv}$. I write $p_{i}$ for the price charged by firm $i, p$ for a strategy profile, i.e. a vector in $R_{+}^{n}$ and $p_{-i}$ for the vector of prices charged by all firms but $i$, that is $p_{-i}=\left(p_{1}, \ldots, p_{i-1}, p_{i+1}, \ldots, p_{n}\right)$.

A3) Demand. Consumers choose the firm to buy from according to a random process that is not affected by firms' pricing strategies. However, I allow the distribution of demand among firms to depend on other factors. ${ }^{7}$ This means that any market share distribution is possible. The only restriction imposed is that all active firms have a positive market share. Hence: $\alpha_{i}>0$ and $\sum_{i=1}^{n} \alpha_{i}=1$

Finally, market demand is described by a concave and decreasing demand function, $q=q\left(p^{e}\right)$, with $q\left(p^{e}\right)=0$ for $p^{e} \geq \bar{p}$, where $p^{e}=\sum_{i=1}^{n} \alpha_{i} p_{i}$ is the expected price. Given concavity of the demand function, $p^{e} q\left(p^{e}\right)$ is strictly concave, and $p^{m}$ denotes its unique maximizer. 
Summarizing, every firm faces the following demand function:

$$
q_{i}(p)=\alpha_{i} q\left(p^{e}\right)
$$

\section{ANALYSIS}

The firms' payoffs are:

$$
\pi_{i}=p_{i} \alpha_{i} q\left(p^{e}\right) \quad i=1, \ldots n
$$

Given the strict concavity of (2) they have a unique maximum for any $p_{-i}$. We can restrict attention to first order conditions. Posing them and rearranging we have:

$$
p_{i}=\frac{q\left(p^{e}\right)}{\alpha_{i}} \frac{d p^{e}}{d q} \quad i=1, \ldots n
$$

Equations (3) define $n$ implicit reaction functions, $R_{i}\left(p_{-i}\right)$. They form the following function $R: R_{\dashv}^{n}$ $\rightarrow R_{\dashv}^{n}, R=\times{ }_{i} R_{i}\left(p_{-i}\right)$, that is continuously defined on a compact set and thus has a fixed point. At this

fixed point, $p^{*}$, conditions (3) hold and $p^{*}$ represents an equilibrium. The following proposition characterizes the equilibrium.

Proposition. A) The expected equilibrium price, $\mathrm{p}^{\mathrm{e}^{*}}$

(i) equals the monopoly price $\mathrm{p}^{\mathrm{m}}$ if and only if there is only one firm;

(ii) is strictly above the monopoly level in all the other cases;

(iii) increases if the number of firm increases; and

(iv) is independent of the market shares distribution.

B) Firms' prices are inversely related to their market shares.

Proof. A) Given (3) the expected equilibrium price is implicitly defined by: 


$$
p^{e^{*}}=\sum_{i=1}^{n} \alpha_{i} p_{i}^{*}=-n q \frac{d p}{d q}
$$

which, after some manipulation, gives the following implicit function:

$$
\varepsilon\left(p^{e^{*}}\right)=n,
$$

where $\varepsilon\left(p^{e^{*}}\right)$ is the absolute value of the price elasticity of the demand function at $p^{e}=p^{e^{*}}$. Since $p^{e^{*}}$ $=p^{m}$ implies $\varepsilon\left(p^{e^{*}}\right)=1$, equation (4) directly proves statement (i). Given the concavity of the demand function, the absolute value of the price elasticity is a monotone increasing function of the expected price, therefore equation (4) proves that if there is more than one firm in the market the expected equilibrium price is strictly above the monopoly level (statement ii), and that if the number of firms increases the expected equilibrium price increases (statement iii). Market shares do not enter into equation (4) and this proves that the distribution of market shares does not affect the expected equilibrium price (statement iv). Finally, using the implicit function theorem for the implicit reaction functions (3), we can see that $\partial R_{i}\left(p_{-i}\right) / \partial a_{i}<0$. This proves that the smaller the market share of a firm the higher its price (Statement B).

The intuitions behind the results summarized in this proposition are very simple. When a firm sets its price, it considers that this choice will contribute to determining the size of the market - which stems from the decisions of how much to buy made by each consumer - and its own market share which stems from the second decision made by consumers, i.e. "where to buy". In the model the second choice is irrelevant either because there is only one firm or because of search costs. However, when there is only one active firm, the monopolist knows that consumers will respond to price modifications by varying the market size, i.e. the firm's individual demand. Since the expected price equals the price charged by the monopolist, the consequences of a price modification are borne entirely by this firm, which maximizes its profits by charging the monopoly price. If there is more than one firm, but consumers cannot choose where to buy because of search costs, and base their quantity decision on the expected price, each firm knows that a modification of its price will 
not cause a reaction of similar intensity to that which occurs in a monopoly. This is so because the modification of the expected price is smaller since it is equal to the weighted average of all the prices charged in the market. This provides an incentive to increase the price beyond the optimal level from the firm's point of view. This externality becomes stronger as the number of firms increases. Therefore, if a new firm enters the market, all firms bear less the effects of increasing their price. As a consequence, the average equilibrium price will be higher. Given any number of firms, a shift by a proportion of the consumers served by one firm to another firm (i.e. a modification of the market share distribution) makes the demand less respondent to the price policy of the first firm and more respondent to the price policy of the second. Given the linearity of the expected price function, the average equilibrium price eventually does not change. Finally, the larger the market share of a firm, the lower the external effect. This explains why equilibrium prices are inversely related to market shares.

\section{THE MARKET WITH HETEROGENEOUS CONSUMERS}

The model presented in this paper is very simple as all consumers face search costs that prevent them from making an informed choice. However, the main result proved in the previous section is robust to slight modifications of this assumption. In fact, we may assume that some consumers are perfectly informed or, equivalently, have no search costs. These consumers choose the firm that

charges the lowest price and base and their quantity decision on this price. ${ }^{8}$ The equilibrium in a model with heterogeneous consumers is in pure strategies if there are few informed consumers and in mixed strategies if the proportion of informed consumers is large. In the first case the main result of the paper is not affected. The expected equilibrium price remains above the monopoly price. 


\section{CONCLUSIONS}

In this paper I have analyzed a model where consumers choose quantity based on the expected price and face search costs when they have to select a firm. The main result of the paper is that firms respond to this behavior by charging prices that are too high, also from their point of view, as the expected equilibrium price is above the monopoly level. This result also holds in a market where some consumers are perfectly informed and choose firms and quantity according to the lowest price available in the market. The model explains why some firms may want price controls that limit their ability to increase prices. In this situation self-regulation, even if it takes the form of a price-fixing agreement that may deemed to infringe antitrust provisions, leads to lower prices and higher quantity and profits and therefore results in a Pareto superior outcome. 


\section{REFERENCES}

Beggs, A. W and Klemperer, P., 1992, "Multi-Period Competition with Switching Costs", Econometrica, 60, pp. 651-666.

Buccirossi, P., 2001, "Price Competition and a Probabilistic Demand Yield the Cournot Outcome, the Bertrand Outcome and Much More”, Working Paper no. 41, University of Rome La Sapienza, http://dep.eco.uniroma1.it/

Diamond, P., 1971, “A Model of Price Adjustment”, Journal of Economic Theory, 3, pp. 156-168.

Klemperer, P., 1987a, “The Competitiveness of Markets with Switching Costs”, Rand Journal of Economics, 18, pp. 138-150.

Klemperer, P., 1987b, "Markets with Consumer Switching Costs”, Quarterly Journal of Economics, 102, pp. 375-394.

Salop, S. and Stiglitz, J., 1977, "Bargains and Rip-offs: A Model of Monopolistically Competitive Price Dispersion”, Review of Economic Studies, 44, pp. 493-510.

Stahl, D. O., 1996, "Oligopolistic Pricing with Heterogeneous Consumer Search”, International Journal of Industrial Organization, 14, pp. 243-268.

Stigler, G., 1961, “The Economics of Information”, Journal of Political Economy, 69, pp. 213-225.

Stiglitz, J., 1987, "Competition and the Number of Firms in a Market: Are Duopolies More Competitive than Atomistic Markets?”, Journal of Political Economy, 95, pp. 1041-1061.

To, T., 1996, "Multi-Period Competition with Switching Costs: An Overlapping Generations Formulation", Journal of Industrial Economics, 64, pp. 81-87.

Varian, H., 1980, “A Model of Sales”, American Economic Review, 70, pp. 651-659.

von Weizsacker, C. C., 1984, “The Costs of Substitution”, Econometrica, 52, pp. 1085-1116. 


\section{FOOTNOTES}

1 This may happen, for instance, because the existence of corruption makes the choice of the supplier dependent on the bribes offered to the public officials.

2 Among them: Diamond [1971], Salop and Stiglitz [1977], Varian [1980] Stiglitz [1987], Stahl [1996].

3 See Klemperer [1987a, 1987b], Beggs and Klemperer [1992], To [1996]; see also von Weizsacker [1984] for an early analysis of switching costs.

4 Note that, in order to affect the behavior of demand, searching costs do not need to be high in absolute values. It suffices that they are above the benefits the agent can obtain from searching. If these benefits are zero because the agent is not charged for the purchase and is not compensated for buying at a lower price, as it may be for a doctor or a public official, even small search costs are sufficient to prevent the agent from searching.

5 For a model in which these probabilities are continuous functions of the prices charged by all the firms that offer the product see Buccirossi [2001].

6 Some antitrust cases provide a good example of this attitude. In 1999 the Italian Competition Authority investigated two cases in the pharmaceutical sector. In the first case, some companies were accused of fixing the price of a specific drug after a law had liberalized the price. The companies argued that their discussions on price were aimed at preventing the price from being too high. In the second case, Farmindustria, an Italian trade association of pharmaceutical companies, 
adopted an internal code to limit the price increases for those drugs whose price had been recently liberalized.

7 This might be because we are considering short term competition or subgames where long term decisions have been made already and cannot be changed anymore.

8 The analysis of this version of the model can be found in the supplemental material available on the web site of the Journal. 